\title{
Risk factors for infection by Toxoplasma gondii in herds of goats in Ceará, Brazil
}

\author{
[Fatores de risco para infecção pelo Toxoplasma gondii em rebanhos de caprinos no Ceará, Brasil] \\ A.C.R. Cavalcante ${ }^{1}$, M. Carneiro ${ }^{2}$, A.M.G. Gouveia ${ }^{3}$, R.R. Pinheiro ${ }^{1}$, R.W.A. Vitor ${ }^{2 *}$ \\ ${ }^{1}$ Embrapa Caprinos - Sobral, CE \\ ${ }^{2}$ Instituto de Ciências Biológicas - UFMG \\ Caixa Postal 486 \\ 31270-901 - Belo Horizonte, MG \\ ${ }^{3}$ Escola de Veterinária - UFMG - Belo Horizonte, MG
}

\begin{abstract}
In order to identify possible risk factors for T. gondii infection in goat herds in Ceará, Brazil, 2362 serum samples were tested by ELISA. The serological prevalence was $25.1 \%$. The risk factors identified for Toxoplasma gondii infection in goat herds were age, number of cats, use of wooden feeding troughs and absence of feeding troughs. Goats older than 37 months had 2.01 (CI 95\%; $1.55-2.61$ ) higher risk of infection than younger animals. Greater risk of infection was observed in farms with more than 10 cats $(\mathrm{OR}=1.73$; CI $95 \% ; 1.01-3.33)$. The use of wooden feeding troughs represented a high probability of infection $(\mathrm{OR}=7.81$; CI 95\%; $1.66-36.67)$. The lack of feeding troughs also represented a high probability of infection $(\mathrm{OR}=5.50 ; \mathrm{CI} 95 \% ; 1.24-24.39)$.
\end{abstract}

Keywords. goat, prevalence, Toxoplasma gondii, risk factor, Ceará

\section{RESUMO}

Com o objetivo de se identificarem os fatores de risco associados à presença de infecção por toxoplasmose em rebanhos caprinos no estado do Ceará, Brasil, soros sanguíneos de 2362 caprinos foram testados por meio de ELISA. A prevalência estimada pelo ELISA foi $25,1 \%$. Os fatores de risco identificados nas propriedades foram: idade dos animais, número de gatos, comedouro manufaturado de madeira e ausência de comedouro. Em caprinos com mais de 37 meses de idade o risco de estarem infectados pelo $\mathrm{T}$. gondii foi 2,01 vezes maior (IC 95\%; 1,55 - 2,61) que em animais mais jovens. Maior risco de infecção foi observado em fazendas com mais de 10 gatos (OR = 1,73; IC 95\% 1,01 - 3,33). Quando a propriedade utilizava comedouros de madeira, o risco de estarem infectados foi também maior $(O R=7.81 ;$ IC 95\%; 1.66 - 36.67). Animais oriundos de propriedades sem comedouro também apresentaram alto risco de infecção $(O R=5.50 ;$ IC 95\%; 1,24-24,39).

Palavras-chave caprino, prevalência, Toxoplasma gondii, fator de risco, Ceará

\section{INTRODUCTION}

Toxoplasmosis, caused by the parasite Toxoplasma gondii, is one of the most common parasitic zoonosis worldwide. The major routes of transmission may depend on both eating and cultural habits. The former is frequently related with eating raw or undercooked meat containing tissue cysts as well as ingesting water or vegetables contaminated with sporulated oocysts (Tenter et al., 2000); the latter is associated with the presence of cats, in which the parasite sexual cycle occurs. Indeed, cats are the main reservoirs of infection as they are the only host that excretes environmentally resistant oocysts (Dubey, 2004). The relative importance of these two routes varies according to geographical, sociological and hygienic factors.

Recebido em 18 de outubro de 2006

Aceito em 31 de janeiro de 2008

*Autor para correspondência (corresponding author)

E-mail: ricardovitor@icb.ufmg.br 
Toxoplasma gondii uses a wide range of warmblooded intermediate hosts including the goat. Information on the seroprevalence of antibodies against $T$. gondii in goats has been reported in various countries, suggesting that these animals constitute important hosts (Machado et al., 1987). When undercooked, the meat or unpasteurised milk may be important sources of human infection (Tenter et al., 2000).

Limited epidemiological information regarding caprine toxoplasmosis risk factors is available in literature. A strong relationship between age and positive seroprevalence for $T$. gondii has been reported in goat herds worldwide. Young animals show lower prevalences of $T$. gondii antibodies than do adults (Sella et al., 1994; Tenter et al., 2000; Figueiredo et al., 2001; Figliuolo et al., 2004).

Farm management factors have also been related with positive prevalence of caprine toxoplasmosis. Machado et al. (1987) observed a seroprevalence of $11.4 \%$ for toxoplasmosis in goats reared for meat production in the state of Minas Gerais, Brazil. Among dairy herds, the proportion of positive goats was $36.1 \%$. Jittapalapong et al. (2005) reported a positive seroprevalence of $27.9 \%$ for toxoplasmosis in goat herds in the south of Thailand. These authors evidenced a close relationship between toxoplasmosis in goats and factors such as advanced age, the female gender and dairy production.

The economic importance of $T$. gondii in caprine herds lies in abortion and neonatal loss that may be repeated in subsequent gestations (Dubey, 1982). A primary infection in pregnant goats can establish a placental and fetal infection which may result in fetal death, resorption, abortion or stillbirth (Dubey et al., 1986; Chanton-Greutmann et al., 2002). Abortions without definite diagnosis have been observed in goats from the different states of the Northeast region of Brazil, where these animals are important to the local economy (Pinheiro et al., 2000; Silva et al., 2005; Bandeira et al., 2007).

The objective of the present study was to identify possible risk factors for $T$. gondii infection in goat herds in Ceará, Brazil.

\section{MATERIAL AND METHODS}

Seventy two herds of goats from different mesoregions of Ceará were studied. A nonprobabilistic sampling method was used to select herds. This method was chosen due to the lack of a representative list of goat herds in the state. As sampling universe, rural properties listed by Brazilian governmental organs and breeders associations were selected. Such information sources were used to identify the principal areas of goat breeding, within the sampling universe, and to establish local contacts.

Blood samples were drawn into vacuum tubes from the jugular veins of 2362 goats. After centrifugation, sera samples were stored at $-20^{\circ} \mathrm{C}$ until serological tests could be performed. Samples were tested in duplicate by ELISA according to Vitor et al. (1999). The cut-off value for each ELISA plate was calculated as the mean absorbance of serum samples obtained from eight goats negative for $T$. gondii, plus three standard deviations. The absorbance value provided for each goat was divided by the cut-off value to determine the reactivity index (RI). Sera with $R I$ values $\geq 1$ were considered positive.

The owner of each farm was interviewed using a pre-coded questionnaire especially designed for this study. Interviews were carried out by trained interviewers provided with an instruction manual. Information on the farm and herds was collected including: (1) characterization of each farm (water supply, type of water facility, feeding troughs, facilities (buildings, equipments, pen flooring), topography, land use (extensive/intensive)); (2) presence of cats (number of domestic cats, access of these animals to water supplies and feeding places for goats, feeding of cats with placental remains, (3) individual animal data (age, sex and breed of each animal sampled).

A minimum sample size $(n=2340$ goats $)$ for this study was estimated according to Astudilho (1979), using the following parameters: 1) expected prevalence: $36 \%$, which is the median of studies conducted in different areas (Chiari et al., 1987; Alves et al., 1997); (2) determinant factor of degree of confidence $=1.96$; sampling error $15 \%$ prevalence. On each farm, the proportion of $20 \%$ of the total number of animals was selected. 
Information collected in the questionnaires and results of the serological analyses were coded and entered on the computer using the Windows Excel software. The softwares Epi-Info 6.04 (Dean et al., 1992) and Stata 9.0 (Statacorp, 2005) were used to analyze data. Identification of risk factors associated with $T$. gondii infection was performed using logistic regression with random-effects. Due to the hierarchical structure of our data (2362 goats in 72 herds), the statistical unit for analysis was the herd. Interdependence among subunits, goats belonging to the same herd, was taken into account.

A univariate analysis was used initially for all the variables under study considered to be relevant to toxoplasmosis in goats. The association between toxoplasmosis and each variable was found by calculating the odds ratio (OR), with a confidence interval of $95 \%$. Categorical variables were transformed into indicator variables (dummies). Variables in this phase with significance statistical level of $\mathrm{P}<0.20$ and some variables with no significant differences, but considered to be relevant as risk factor for $T$. gondii infection, were selected for multivariate analysis. Variables that presented colinearity or low frequency were excluded from the multivariate model.

For the model building process, all the variables selected for univariate analysis were included, and the final model was constructed using the backward process, which was evaluated by likelihood ratio tests. The significance statistical level was $\mathrm{P}<0.05$ (Diggle et al., 1994)

\section{RESULTS}

Out of the 2362 goats under study, comprising $2029(85.9 \%)$ female and $333(14.1 \%)$ male, the age distribution of the animals was: $525(22.2 \%)$ $\leq 12$ months; 527 (22.3\%) 13-24 months; 1177 (49.8\%) 25-36 months and $133 \quad(5.4 \%) \geq 37$ months. With regard to breed, our data provided the following proportions: $567(24.0 \%)$ pure breed (Anglo Nubiana, Bujh, Canidé, Moxoto, Parda Alpina and Saanem); 1482 (62.7\%) crossbreed and; $313(13.3 \%)$ undetermined breed. Goats were reared extensively $(75.0 \%)$ or semi-extensively (20.8\%) and destined for slaughter on almost all the farms.

ELISA serum analysis of the 2362 samples showed that $594(25.1 \%)$ animals were reactive to ELISA with the following distribution of RI values: $1768(74.9 \%)<1 ; 149(6.3 \%)>1$ and $<2 ; 316(13.4 \%) \geq 2$ and $<4 ; 85(3.6 \%) \geq 4$ and $<6$; and $44(1.8 \%) \geq 6$. According to the age distribution, a significantly higher prevalence of $T$. gondii antibodies was observed in older animals when compared with younger ones $(\leq 12$ months: $14.6 \%$; $13-24$ months: $22.0 \%$; $25-36$ months: $28.2 \%$; $\geq 37$ months: $50.4 \%$ ). No significant difference was observed in $T$. gondii prevalence between female $(25.7 \%)$ and male $(21.9 \%)$ goats.

Characterization of the herds, variables related to the presence of cats in the 72 herds and individual characteristics related to the goats (n $=2362$ ) are presented in Table 1. Although univariate analysis was conducted by taking into account all the variables collected, only those selected for multivariate analysis based on $\mathrm{P}<0.20$ constituting relevance to risk factors for $T$. gondii infection are presented.

The variables related to the individual characteristics of the animals selected for multivariate analysis were: age (categorized as $\geq 37$ vs $<37$ months) and sex (female vs male). The variables related to the herd characteristics selected for multivariate analysis were: exposed water source (pond, river/lake vs no exposed water), type of drinking trough (rubber tire or absent vs cement), type of feeding trough (wooden or absent compared to cement-mixed), type of floor surface (ground floor or mixed vs cement or stone), type of pen (ground level or mixed vs raised), rearing regime (intensive or semi-extensive vs extensive), type of breed (milk or meat vs mixed). Characteristics related to cats included: number of cats (categorized as $\geq 10$ vs $<10$ cats), access of cats to water supplies (yes vs no), access of the cats to the feeding facilities (yes vs no), cats feeding on placental remains (yes vs no).

The final multivariate model with the adjusted $\mathrm{OR}$ and their respective confidence intervals are depicted in Table 2. Remaining variables for the final model were: wooden feeding trough $(\mathrm{OR}=$ 7.81 ; CI 95\%; 1.66 - 36.67), absence of feeding trough $(\mathrm{OR}=5.50 ;$ CI 95\%; $1.24-24)$, more than 10 cats per farm $(\mathrm{OR}=1.73$; CI $95 \% ; 1.01$ $-3.33)$ and animal age over 37 months $(2.01$; CI $95 \% ; 1.55-2.61)$. 
Risk factors for infection...

Table 1. Frequency of variables selected in univariate analysis to evaluate the sero-epidemiological aspects of caprine toxoplasmosis in Ceará, Brazil.

\begin{tabular}{|c|c|c|c|c|}
\hline & $\begin{array}{l}\text { Herds or goats } \\
\mathrm{n}(\%)\end{array}$ & OR & CI $95 \%$ & P-value \\
\hline Characteristics of herds & $(\mathrm{N}=72)$ & & & \\
\hline \multicolumn{5}{|l|}{ Water source $(\mathrm{n}, \%)$} \\
\hline Absent & $1(1.5)$ & 1 & & \\
\hline Pond & $56(86.2)$ & 0.25 & $0.02-3,15$ & 0.249 \\
\hline River/Lake & $8(12.3)$ & 0.48 & $0.02-6.04$ & 0.483 \\
\hline \multicolumn{5}{|l|}{ Type of drinking trough $(\mathrm{n}, \%)$} \\
\hline Cement & $12(26.1)$ & 1 & & \\
\hline Tire & $2(4.3)$ & 1.35 & $0.28-6.39$ & 0.705 \\
\hline Absent & $32(69.6)$ & 0.63 & $0.31-1.29$ & 0.209 \\
\hline \multicolumn{5}{|l|}{ Type of feeding trough (n, \%) } \\
\hline Cement/mixed & $6(12)$. & 1 & & \\
\hline Wood & $11(22.4)$ & 10.84 & $2.18-53.89$ & 0.004 \\
\hline Absent & $32(65.3)$ & 6.73 & $1.41-31.9$ & 0.016 \\
\hline \multicolumn{5}{|l|}{ Type of pen (n, \%) } \\
\hline Raised & $12(16.7)$ & 1 & & \\
\hline Ground level & $53(72.3)$ & 0.51 & $0.23-1.15$ & 0.106 \\
\hline Mixed & $7(9.7)$ & 0.35 & $0.10-1.19$ & 0.094 \\
\hline \multicolumn{5}{|l|}{ Pen flooring $(\mathrm{n}, \%)$} \\
\hline Cement/Stone & $4(6.2)$ & 1 & & \\
\hline Ground floor & $47(72.3)$ & 0.87 & $0.39-1.97$ & 0.743 \\
\hline Mixed & $14(21.5)$ & 1.37 & 0.375 .01 & 0.034 \\
\hline \multicolumn{5}{|l|}{ Type of terrain (n, \%) } \\
\hline Flat/Hilly & $40(56,3)$ & 1 & & \\
\hline Hilly/periodically flooded & $31(43.7)$ & 0.71 & $0,09-5.08$ & 0.734 \\
\hline \multicolumn{5}{|l|}{ Breed type (n, \%) } \\
\hline Meat/Milk & $20(27.8)$ & 1 & & \\
\hline Meat & $47(65.3)$ & 1.08 & $0.55-2.14$ & 0.829 \\
\hline Milk & $5(6.9)$ & 3.20 & $0.81-12.67$ & 0.010 \\
\hline \multicolumn{5}{|l|}{ Management system (n, \%) } \\
\hline Extensive & $54(75.0)$ & 1 & & \\
\hline Intensive & $2(2.8)$ & 1.76 & $1.01-3.04$ & 0.043 \\
\hline Semi-extensive & $16(22.2)$ & 1.42 & $0.68-2.99$ & 0.344 \\
\hline $\begin{array}{l}\text { Access of cats to water supplies } \\
(\mathrm{n}, \%)\end{array}$ & $12(12.7)$ & 1.00 & $0.53-1.87$ & 0.985 \\
\hline $\begin{array}{l}\text { Access of cats to feeding facilities } \\
(\mathrm{n}, \%)\end{array}$ & $30(41.7)$ & 1.53 & $0.83-2.84$ & 0.172 \\
\hline $\begin{array}{l}\text { Cats fed with placental remains } \\
\text { no vs yes }(\%)\end{array}$ & $24(33.3)$ & 1,63 & $0,84-3.03$ & 0,141 \\
\hline $\begin{array}{l}\text { Presence of cats }(\geq 10 \text { vs }<10 \text { by } \\
\text { farm) }\end{array}$ & $15(20.83)$ & 2.41 & $1.18-4.91$ & 0.002 \\
\hline Characteristics of Goats & $(\mathrm{N}=2362)$ & & & \\
\hline Age $(\geq 37$ vs $<37$ months $)$ & $559(23.7)$ & 1,98 & $1.58-2.48$ & 0.000 \\
\hline Sex: $\mathrm{n}=$ females $(\%)$ & $2381(85.9)$ & 1.12 & $0.82-1.56$ & 0.456 \\
\hline Breed (without breed vs others & $1795(76.2)$ & 0.87 & $0.65-1.17$ & 0.371 \\
\hline
\end{tabular}

Missing data are not shown; OR: odds ratio; CI: confidence interval 
Table 2. Final model of infection by Toxoplasma gondii in goats in Ceará, Brazil.

\begin{tabular}{lc} 
Variable & Adjusted OR (CI 95\%) \\
\hline Wooden feeding trough (yes) & $7.81(1.66-36.67)$ \\
Feeding trough absent (yes) & $5.50(1.24-24.39)$ \\
Presence of $\geq 10$ cats per farm (yes) & $1.73(1.01-3.33)$ \\
Animal age over 37 months & $2.01(1.55-2.61)$ \\
\hline \multicolumn{2}{c}{ OR: odds ratio; CI: confidence interval }
\end{tabular}

OR: odds ratio; $\mathrm{CI}$ : confidence interval

\section{DISCUSSION AND CONCLUSIONS}

The prevalence of goat toxoplasmosis in the Brazilian state of Ceará was $25.1 \%$. Values ranging from 0 to $92.4 \%$ have been previously observed in Brazil (Chiari et al., 1987; Alves et al., 1997). The risk factors for $T$. gondii infection in goat herds in Ceará were: age, number of cats, wooden feeding trough and absence of feeding trough.

An association was found between toxoplasmosis infection and age, showing that animals over 37 months had a 2.01 times greater risk than younger animals. Age is the most widely discussed variable in literature, and its association with infection has been demonstrated in numerous studies (Sella et al., 1994; Figueiredo et al., 2001; Silva et al., 2003). A longer exposure to different risk factors may account for the greater prevalence of toxoplasmosis in older goats in the present investigation

With respect to the effect of the presence of cats, multivariate analysis showed that the probability of infection was higher in herds where more than 10 cats were present $(\mathrm{OR}=1.73$; CI 95\%; $1.01-$ 3.33). It may be related to greater environmental contamination by oocysts eliminated in cat feces. Other studies have reported increased positive seroprevalence of human toxoplasmosis in workers on pig farms in Illinois, USA, closely related with the number of cats in the properties (Weigel et al., 1999). These authors have also correlated high positive seroprevalence values with management systems, suggesting that direct contact with the soil is the primary mode of transmission of $T$. gondii to humans.

The extensive management system predominates in goat farms in Ceará. In this system, the animals are allowed to roam free on pasture during the day, being sheltered from the natural environment during the night. Generally, goats are reared together with other ruminants, mainly sheep. During the dry season, characterized by long dry periods and scarcity of pasture, feeding supplements based on any food available are offered, from crop remnants to leftovers (Pinheiro et al., 2000). This attracts cats not only to pastures, but also to the pens into which the animals are herded. In these sites the cats defecate and eliminate oocysts, contaminating the environment, as well as the food and water offered.

Goats were 7.81 times more likely to be infected in herds where wooden feeding troughs were used. The capacity of these troughs to retain moisture into the shady pens probably favors the survival of oocysts deposited together with the feces from cats frequently present in the facilities. The lack of feeding troughs also represented a high probability of infection $(\mathrm{OR}=$ 5.36). The absence of troughs on these goat farms is probably due to the fact that supplementary feeding was not performed. Thus, the animals would contract toxoplasmosis from pasture or water contaminated with sporulated oocysts.

The observed risk factors in the present study indicates that increasing age of goats, number of cats, exposed feeding troughs and absence of feeding troughs are all associated with caprine toxoplasmosis in Ceará, probably by permitting the survival of sporulated oocysts of $T$. gondii which contaminate environments occupied by the animals.

\section{ACKNOWLEDGMENTS}

The authors gratefully acknowledge Mrs. Rosálida Estevan Nasar Lopes for technical support and Dr. Bruce Alexander for revising the manuscript. R.W.A.V is Research Fellow from CNPq. 


\section{REFERENCES}

ASTUDILLO, V.M. (Ed). Encuestas por muestro para estudios epidemiológicos en populaciones animales. Rio de Janeiro: Centro Panamericano de Fiebre Aftosa, 1979. 60p.

ALVES, C.J.; VASCONCELLOS, S.A.; NAVARRO, I.T. et al. Avaliação de aglutininas anti-Toxoplasma em soros de caprinos de cinco centros de criação do nordeste do Brasil. Rev. Bras. Cien. Vet., v.4, p.75-77,1997.

BANDEIRA, D.A.; CASTRO, R.S.; AZEVEDO, E.O. et al. Perfil sanitário e zootécnico de rebanhos caprinos nas microrregiões do Cariri paraibano. Arq. Bras. Med. Vet. Zootec., v.59, p.1597-1600, 2007.

CHANTON-GREUTMANN, H.; THOMA, R.; CORBOZ, L. et al. Abortion in small ruminants in Switzerland: investigations during two lambing seasons (1996-1998) with special regard to chlamydial abortions. Schweiz. Arch. Tierheilkd., v.144, p.483-492, 2002.

CHIARI, C.A.; LIMA, J.D.; LIMA, W.S. et al. Soro-Epidemiologia da Toxoplasmose Caprina em Minas Gerais, Brasil. Arq. Bras. Med. Vet. Zootec., v.39, p.587-600, 1987.

DEAN, A.G.; DEAN, J.A.; BURTON, A.J. et al. EPIINFO, a word processing, date base and statistics program for epidemiology on microcomputers: version 6 Georgia: USD, 1992.

DIGGLE, P.J.; LIANG, K.Y.; ZEGER, S. L. (Eds). Analysis of longitudinal data. Oxford: Clarendon, 1994. 292p.

DUBEY, J.P. Repeat transplacental transfer of Toxoplasma gondii in dairy goats. J. Am. Vet. Med. Assoc., v.180, p.1220-1221, 1982.

DUBEY, J.P.; MILLER, S.; DESMONTS, G. et al. Toxoplasma gondii-induced abortion in dairy goats. J. Am. Vet. Med. Assoc., v.188, p.159-162, 1986.

DUBEY J.P. Toxoplasmosis - a waterborne zoonosis. Vet. Parasitol., v.126, p.57-72, 2004.

FIGLIUOLO, L.P.C.; RODRIGUES, A.A.R.; VIANA, R.B. et al. Prevalence of anti-Toxoplasma gondii and anti-Neospora caninum antibodies in goat from São Paulo State, Brazil. Small Rumin. Res., v.55, p.29-32, 2004.

FIGUEIREDO, J.F.; SILVA, D.A.; CABRAL, D.D. et al. Seroprevalence of Toxoplasma gondii infection in Goats by the indirect haemaglutination, immunofluorescence and immunoenzymatic tests in the region of Uberlândia, Brazil. Mem. Inst. Oswaldo Cruz., v.96, p.687-692, 2001.

JITTAPALAPONG， S.; SANGVARANOND， A.; PINYOPANUWAT, N. et al. Seroprevalence of Toxoplasma gondii infection in domestic goats in Satun Province, Thailand. Vet. Parasitol., v.4, p.17-22, 2005.

MACHADO, T.M.M.; LIMA, J.D. Freqüência de anticorpos anti-Toxoplasma gondii em caprinos criados sob diferentes formas de exploração no estado de Minas Gerais. Arq. Bras. Med. Vet. Zootec., v.39, p.255-264, 1987.

PINHEIRO, R.R.; GOUVEIA, A.M.G.; ALVES, F.S.A. et al. Aspectos epidemiológicos da caprinocultura cearense. Arq. Bras. Med. Vet. Zootec., v.52, p.534-543, 2000.

SELLA, M.Z.; NAVARRO, I.T.; VIDOTTO, O. et al. Epidemiologia da toxoplasmose caprina: levantamento sorológico do Toxoplasma gondii em caprinos leiteiros na microrregião de Londrina, Paraná, Brasil. Rev. Bras. Parasitol. Vet., v.3, p.1316, 1994.

SILVA, A.V.; CUNHA, E.L.P.; MEIRELES, L.R. et al Sheep and goat toxoplasmosis: soroepidemiological study in two regions in the State of Pernambuco, Brazil. Cienc. Rural, v.33, p.115-119, 2003.

SILVA, J.S.; CASTRO, R.S.; MELO, C.B. et al. Infecção pelo vírus da artrite encefalite caprina no Rio Grande. Arq. Bras. Med. Vet. Zootec., v.57, p.726-731, 2005 .

STATACORP, Stata Statiscal Software: Release 9.0. College Station, TX: Stata Corporation, 2005.

TENTER, A.M.; HECKEROTH, A.R.; WEIIS, M.L. Toxoplasma gondii: from animals to humans. Int. J. Parasitol., v.30, p.1217-1258, 2000.

VITOR, R.W.A.; FERREIRA, A.M.; FUX, B. Antibody response in goats experimentally infected with Toxoplasma gondii. Vet. Parasitol., v.81, p.259-263, 1999.

WEIGEL, R.M.; DUBEY, J.P.; DYER, D. et al. Risk factors for infection with Toxoplasma gondii for residents and workers on swine farms in Illinois. Am. J. Trop. Med. Hyg., v.60, p.793-798, 1999. 